
World Ecology

\title{
The potential role of virtual water in solving water scarcity and food security problems in China
}

Jingzhu Zhao , Wenhua Liu \& Hongbing Deng

To cite this article: Jingzhu Zhao, Wenhua Liu \& Hongbing Deng (2005) The potential role of virtual water in solving water scarcity and food security problems in China, International Journal of Sustainable Development \& World Ecology, 12:4, 419-428, DOI: $\underline{10.1080 / 13504500509469651}$

To link to this article: http://dx.doi.org/10.1080/13504500509469651

曲 Published online: 24 Nov 2009.

Submit your article to this journal

Џ Article views: 144

Q View related articles $\square$

Citing articles: 5 View citing articles 4 


\title{
The potential role of virtual water in solving water scarcity and food security problems in China
}

Jingzhu Zhao, Wenhua Liu and Hongbing Deng

Key Laboratory of Systems Ecology, Research Center for Eco-Environmental Sciences, Chinese Academy of Sciences, Beijing, China

Key words: Policy relevance, agriculture, food production, water resources, food imports

\begin{abstract}
SUMMARY
Water, as a source of food security, plays an essential role in ensuring sustainable food resources for a growing population. However, water scarcity has increasingly become a constraint to economic development, particularly food production. The water-food challenge is impending because of China's increasing population and water demand. The concept of virtual water is useful to analyze this problem. In this paper, the implications and policy relevance of virtual water are expounded. Based on imported food volumes, it is calculated that an annual average of $10.52 \times 10^{9} \mathrm{~m}^{3}$ of virtual water embodied in imported wheat and maize in the period between 1990 and 2000 is equivalent to $23 \%$ of the annual average transfer water volume of the South-North Water Transfer (SNWT) project. Consequently, this $29.3 \times 10^{6}$ ha of virtual land is equivalent to $19 \%$ of China's arable land in 2000. Using the grain import prediction and the agricultural production conditions of China, the virtual water equivalents of China in 2010 and 2020 are evaluated, and are about $88 \times 10^{9} \mathrm{~m}^{3}$ in 2010 and $95 \times 10^{9} \mathrm{~m}^{3}$ in 2020 , respectively. Importing virtual water embedded in traded food can alleviate water stress and even achieve food security. Virtual water trade may compensate for water demands for not only the past but also the future. Meanwhile, water trade can store water in its virtual water form, enabling food storage to play a potential role in solving food problems, as well as promoting sustainability of water resources in China.
\end{abstract}

\section{INTRODUCTION}

Water, as a source of food security, plays an essential role in ensuring sustainable food resources for a growing population. However, water scarcity is a common problem in many countries and regions. Because of the uneven distribution of water resources and population densities worldwide, water demand already exceeds water supply in nearly 80 countries that support more than $40 \%$ of

the world's population (Bennett 2000). Water scarcity has become an increasing constraint to their economic development, particularly food production - the biggest water user (Hong et al. 2002). Nonrenewable fossil water has been exploited to relieve the immediate pressure of water stress; this use has caused the depletion of resources and obstruction of future economic development and

Correspondence: Wenhua Liu, Key Laboratory of Systems Ecology, Research Center for Eco-Environmental Sciences, Chinese Academy of Sciences, 18 Shuangqing Road, Haidian District, Beijing 100085, China. Email: Lwillow0531@yahoo.com.cn 
food security. To combat water scarcity and increasing food production, many countries have made efforts to expand irrigation (Barker et al. 2001; Bouwer 2000; Postel 1999; Rosegrant et al. 1997; Wichelns 2001). Despite a tremendous effort, the coverage ratio of irrigation in most of these countries remains low, simply because of their scarce water resources. The growth of food production overall has lagged and has been unstable (FAO 2001). In contrast to food production, the growth of population and food demand has been rapid in China. Meeting the water-food challenge is difficult in China because of the increasing population and water demand. In order to relieve water stress, many investment projects in China are planned and have been carried out, in order to focus on changing the uneven distribution of water resources, and to fill the gap between water supply and demand The role of virtual water through food trade as a solution to water scarcity is not recognised in China. Indeed, most researchers do not associate the international food trade with food security. However, they now advocate regional food trading as a solution to water stress in Northern China. These opinions are consistent with Chinese governmen policies of food security. The considerations of the Chinese government for food trade include domestic food security and social stability, the impact on rural employment when grain production remain the major provider of employment in rural areas, and the pressure of rural-urban migration and the social economic impacts on cities (Hong 2002).

\section{WATER DEFICIT AND DEMAND}

\section{Water scarcity in agricultural production}

The increasing demand for food needs two basic natural resources for its production, arable land and fresh water. Future food production depends on the availability of adequate and sustainable water resources. Agriculture is responsible for about $70 \%$ of all freshwater withdrawn, and it is expected that more water will be used for irrigation as world food production increases. An FAO study of 93 developing countries indicates that some water-scarce nations are already withdrawing water supplies faster than they can be renewed (FAO 2004). Over the years, China has maintained a population increase of $1.4 \%$ and an increase in economic development of $9 \%$ per year through using a great deal of water with low efficiency. However, agricultural irrigation is constrained by water scarcity and pollution, with $70 \%$ of food output produced on irrigated land, and $73 \%$ of the total available water used for irrigation. Furthermore, agriculture is in fierce competition with industry, municipal, living and environment water uses. Actually, in China, agriculture competition for water is below industrial and domestic demands (Hong 1999) because the direct economic output of agricultural production is rather low.

In China, every $10^{4} \mathrm{~m}^{3}$ of water feeds 4.46 persons. North China, Inner Mongolia, Hebei, Beijing, Tianjin, Shanxi, Henan and Shandong, seven provinces, use about $168.5 \times 10^{9} \mathrm{~m}^{3}$, which only can feed $75 \times 10^{6}$ persons, i.e. $23 \%$ of the total population. The demand for food by the population is met by food produced in Southern China, where farmland is scarce although water resources are relatively sufficient. Present resources meet the demand for food by the large population. Indeed, the requirement for freshwater resources is four times higher than what is normally available. The required capacity for freshwater resources is the lowest of all the resources estimated ( $\mathrm{Qu}$ 1992).

At the national level, it is estimated that there may be enough water available, but some regions will face serious water shortages, with inefficient use and serious pollution. In northern areas, water scarcity and water pollution are serious while floods and water pollution are the main problems in southern areas. $95 \%$ of available water resources in the north have been exploited, while $6 \%$ of water resources have been used in the south. Table 1 shows that water consumption in agriculture increased in North China where land is not a limiting factor for food production. Because water use efficiency is on average $0.4-0.5$, irrigation water in the north is $7.5 \times 10^{3}-12 \times 10^{3} \mathrm{~m}^{3} / \mathrm{ha}$, or $2-5$ times higher than actual crop water demand (Liu 2000). The management of water use is expected to improve for avoiding water waste and enhancing irrigation capacity.

Water scarcity in the north has resulted in higher opportunity cost than that in the south. The huge investment in the South-North Water Transfer Project also supports this viewpoint. For water-scarce China, water use efficiency is much lower than that of developed countries. With the rapid population growth, water stress is becoming a formidable challenge. Meanwhile, when water resource load 
capacity reaches the limit, direct cost of enlargement of food production will quickly increase and result in native food price rises. The most plausible result is that the cost of water for agriculture becomes much higher because of competition between sectors.

\section{Future water demand of agriculture}

Agricultural water consumption is the principal source of total water consumption, and is increasing with growing food demand. Irrigated area has increased, but total irrigation water quantity and withdrawal do not balance. This is due to irrigation efficiency enhancement and new irrigation technology improvements. Total water consumption has increased with unchanged available agricultural water quantity. The increasing water demands of economic development and domestic needs make additional water for agriculture more difficult to find, especially in North China. The large acreage of crop production in this area indicates a large irrigation requirement. The planted acreages of various crops in seven different provinces with a deficit in water demand for irrigation are shown in Table 2.

Because different crops have different irrigation water demands and different arable land acreages in North China (Qian et al. 2001), total irrigation water demand is $48.55 \times 10^{9} \mathrm{~m}^{3} ; 5.00 \times 10^{9} \mathrm{~m}^{3}$ for rice, $26.53 \times 10^{9} \mathrm{~m}^{3}$ for wheat and $17.02 \times 10^{9} \mathrm{~m}^{3}$ for maize. Actual irrigation efficiency in agriculture is quite low (0.4-0.5), thus, actual water demand required to support production in North China is about $97.1 \times 10^{9}$ tonnes. The ratio for agriculture water use accounts for about $57.63 \%$ of total water resources in North China, which irrigated only $53.12 \%$ of its total ploughed acreage. The remainder of the ploughed acreage irrigation demand, as well as other sectors' demands, intensifies water stress, influencing economic development and agricultural production. A water transfer project was selected to alleviate water pressure in North China, but in the view of the economic cost, virtual water trade through food trade may be a better solution for water deficits.

Table 1 Irrigated acreages and irrigation water volumes in typical years in China

\begin{tabular}{ccccccc}
\hline Year & $\begin{array}{c}\text { Irrigated acreage } \\
\left(10^{6} \mathrm{ha}\right)\end{array}$ & $\begin{array}{c}\text { Irrigation water } \\
\left(10^{9} \mathrm{~m}^{3}\right)\end{array}$ & $\begin{array}{c}\text { Irrigation water in total } \\
\text { water use volume }(\%)\end{array}$ & $\begin{array}{c}\text { population } \\
\left(10^{6}\right)\end{array}$ & $\begin{array}{c}\text { farmland acreage } \\
\left(10^{6} \mathrm{ha}\right)\end{array}$ & $\begin{array}{c}\text { Total foodstuff output } \\
\left(10^{9} \mathrm{~kg}\right)\end{array}$ \\
\hline 1949 & 16.00 & 95.6 & 92.0 & 540 & 97.87 & 113.2 \\
1957 & 25.00 & 185.3 & 90.0 & 646 & 111.80 & 195.0 \\
1965 & 32.07 & 235.0 & 85.0 & 725 & 103.60 & 194.5 \\
1980 & 48.87 & 357.4 & 80.5 & 987 & 99.33 & 320.6 \\
1988 & 47.93 & 387.4 & -1 & 1096 & 95.73 & 394.1 \\
1993 & 49.73 & 344.0 & 66.5 & 1185 & 95.07 & 456.5 \\
1997 & 51.27 & 359.8 & 70.4 & 1236 & 95.00 & 494.2 \\
2000 & 53.80 & 378.4 & 68.8 & 1294 & 108.47 & 4622 \\
\hline
\end{tabular}

1 : number is not available.

Table 2 Crop production acreage of North China in $2000 / 10^{6}$ ha

\begin{tabular}{lcccccc}
\hline Province & Total crop acreage & Cereal acreage & Cereals & Rice & Wheat & Maize \\
\hline Beijing & 0.46 & 0.31 & 0.28 & 0.02 & 0.12 & 0.14 \\
Tianjin & 0.53 & 0.35 & 0.30 & 0.02 & 0.12 & 0.13 \\
Hebei & 9.02 & 6.92 & 5.88 & 0.14 & 2.68 & 2.48 \\
Shanxi & 4.04 & 3.19 & 2.33 & 0.01 & 0.89 & 0.79 \\
Inner Mongolia & 5.91 & 4.44 & 2.65 & 0.12 & 0.62 & 1.30 \\
Shandong & 11.15 & 7.36 & 6.44 & 0.18 & 3.75 & 2.41 \\
Henan & 13.14 & 9.03 & 7.74 & 0.46 & 4.92 & 2.20 \\
Total & 44.26 & 31.59 & 25.61 & 0.95 & 13.10 & 9.45 \\
\hline
\end{tabular}

Data source: 2001 statistcs yearbook 


\section{FOOD DEMAND}

\section{Population growth}

The population in China is about 1.3 billion and has been increasing. Expansion of population influences every aspect of social development Insufficient natural (fresh water, land, forest, etc.) and productive resources (e.g. food) originate from population growth. Finite resources cannot support the huge demand of the growing population. Resources allocation ratios are very small. These problems interlace and restrict economic development and social advancement. At the same time, potential risks are concealed in the problems. The population control policy, which confines the number of children in a family, cannot restrict overall growth in the short term because the growth is based on an existing huge population (Figure 1). It is predicted that population growth will be negative in 2050 (Kang 1998). The most important problem is that China must have enough food for the population, whether from food production or imports Freshwater resource scarcity and uneven

Population $\left(10^{6}\right)$

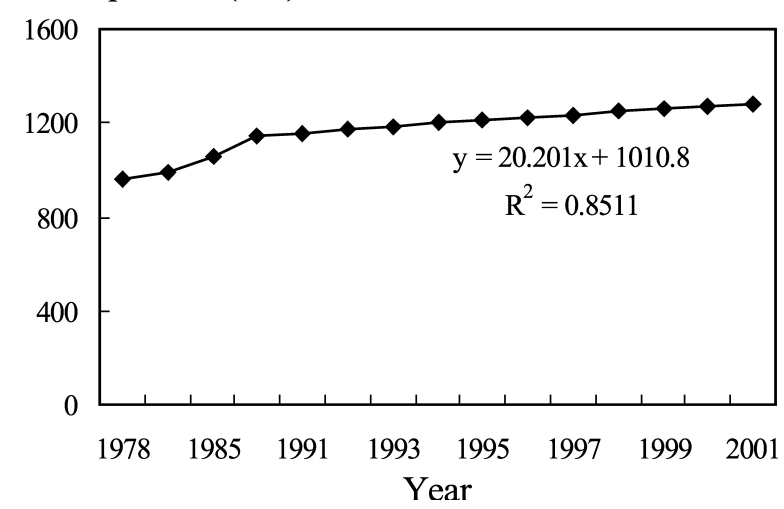

Figure 1 Population growth in China, 1978 to 2001 distribution strain food production, resulting in an increasing portion of domestic food supply coming from imports. Such imports, in essence, have substituted for the water that would otherwise be needed for producing the food locally. Studies of virtual water and food security in Mediterranean and Africa countries have shown that water scarcity in these countries resulted in food insecurity. China has the same food issues, and uneven distribution of water and land resources has resulted in food supply scarcity. Furthermore, there is rising competition between water needed for agriculture and water for domestic use in burgeoning cities and ever-expanding industrial developments. Consequently, today the world must act wisely to conserve, preserve and improve its water supplies (FAO 2004)

\section{Food demand}

Food demand is a function of the size of population and consumption per capita. Rapid population growth will inevitably drive up future food demand, while per capita food consumption is likely to increase as income rises, adding an extra demand for food (Hong et al. 2002). The growth in population and foodstuff demand per capita have jointly promoted the growth of total foodstuff demand in China (Kang 1998). Foodstuff demand requires that food supply increases concomitantly. However, expansion of food production is limited by farmland and water resources; thus, the pathways of food supply enlargement are expected to change (Table 3; Kang 1998; Yan and Chen 2001). Increasing output and food import is required to solve food scarcity, together with water resources, to meet the food demand of the population. Water resources and food trade are complex issues for society.

Table 3 China's food output, demand and import predictions, 2000-2030/10 $0^{6}$

\begin{tabular}{cccccccc}
\hline Year & $\begin{array}{c}\text { Total cereal } \\
\text { demand }\end{array}$ & $\begin{array}{c}\text { Total foodstuff } \\
\text { demand }\end{array}$ & $\begin{array}{c}\text { Total cereal } \\
\text { output }\end{array}$ & $\begin{array}{c}\text { Total foodstuff } \\
\text { output }\end{array}$ & $\begin{array}{c}\text { Cereal import } \\
\text { demand }\end{array}$ & $\begin{array}{c}\text { Foodstuff import } \\
\text { demand }\end{array}$ & $\begin{array}{c}\text { Dependence } \\
\%\end{array}$ \\
\hline 2000 & 446 & 489 & 432 & 455 & 32 & 34 & 7.0 \\
2010 & 509 & 536 & 429 & 452 & 80 & 84 & 15.7 \\
2020 & 536 & 564 & 449 & 473 & 87 & 91 & 16.1 \\
2030 & 557 & 586 & 583 & 614 & $-26^{1}$ & -28 & -4.8 \\
\hline
\end{tabular}

${ }^{1}$ Exports exceed imports, so the numbers are negative. 


\section{CROP PRODUCTION AND FOOD IMPORTS}

\section{Crop production and food consumption}

Cereal production in China provides the basic energy requirement directly as food and indirectly as feed for animals that are used for human consumption. The increase of grain production, including rice, wheat and maize, has been rapid since 1980 (Figure 2). The trend in grain production up to the end of the 1990s was smooth, with only small increases from 1991 to 2000 because land productivity is approaching the limit, and no new productive technology has been created to promote increasing food production. The production of cereals, cotton, oil and sugar was either unchanged or declined, while the production of fisheries and livestock products has rapidly increased (Table 4).

Before 1997 most cereal production was consumed domestically, typically rice, since then, the diet has changed and more non-cereal products are being consumed. With increasing income, meat,

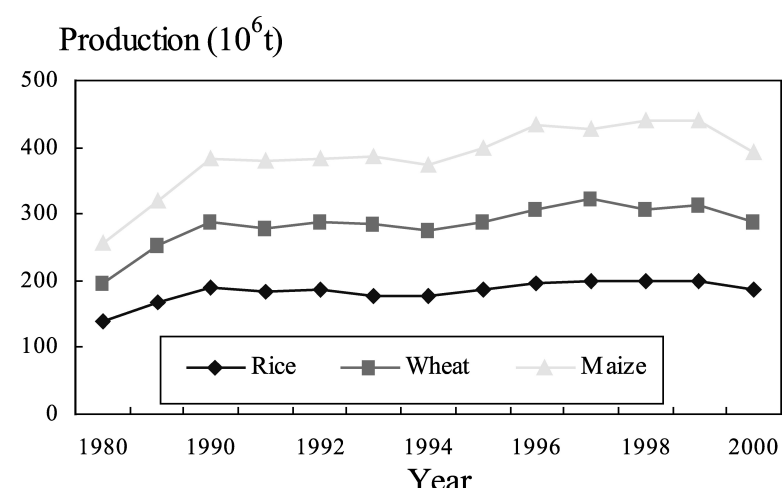

Figure 2 Changes in production of main agricultural products, $1980-2000$ egg and milk demand has increased while cereal consumption has decreased. In contrast to decreasing direct cereal consumption, meat consumption has resulted in indirect cereal consumption by livestock. At present, according to the current GDP per capita, China is positioned by the World Bank in the low-middle income category. However, because of rapid economic development, per capita dietary structure (Table 5) indicates that life quality change is one of the most important variables that influences consumption.

\section{Food trade in the past two decades}

Food imports in China have fluctuated, especially wheat imports. This import demand is decided by domestic production capacity, and is a way to ensure food supply. Production technologies, especially water saving technology and multiple crop index improvement, have promoted the productivity of wheat in China. However, the increase in food production is still limited by water and land resources. Although irrigation efficiency has generally improved, insufficient water resources are allocated to agriculture. Food products imported into China from 1980 to 2000 were mainly in the form of wheat and maize. Net import volume has decreased

Table 5 Per capita food quotient structures, 1980 to 2001 per $\mathrm{kg}$

\begin{tabular}{lcccccr}
\hline Year & 1980 & 1985 & 1990 & 1995 & 2000 & 2001 \\
\hline Cereals & 326.7 & 360.7 & 393.1 & 378.4 & 366.1 & 355.9 \\
Animal products & -1 & - & - & - & 38.3 & 39.5 \\
Fishery products & 4.6 & 6.7 & 10.9 & 19.3 & 33.9 & 34.4 \\
Milk & 1.2 & 2.4 & 3.7 & 4.6 & 6.6 & 8.1 \\
\hline
\end{tabular}

${ }^{1}$ Data are missing

Table 4 Agricultural production situations, 1991 to 2000 per kg

\begin{tabular}{llccccc}
\hline Year & Cereals & Cotton & Oil products & Sugar products & Livestock products & Fishery products \\
\hline 1991 & 378.3 & 4.9 & 14.2 & 73.2 & & 11.7 \\
1992 & 380 & 3.9 & 14.1 & 75.6 & & 13.4 \\
1993 & 387.4 & 3.2 & 15.3 & 64.7 & & 15.5 \\
1994 & 373.5 & 3.6 & 16.7 & 61.3 & & 17.9 \\
1995 & 378.4 & 3.8 & 17.6 & 63.4 & & 19.3 \\
1996 & 414.1 & 3.5 & 18.2 & 68.7 & 30.3 & 23.1 \\
1997 & 401.7 & 3.7 & 17.5 & 76.3 & 33.2 & 31.4 \\
1998 & 412.4 & 3.6 & 18.6 & 78.8 & 37.0 & 32.9 \\
1999 & 405.5 & 3.1 & 20.7 & 66.5 & 38.0 & 33.9 \\
2000 & 366.1 & 3.5 & 23.4 & 60.5 & 38.3 & \\
\hline
\end{tabular}

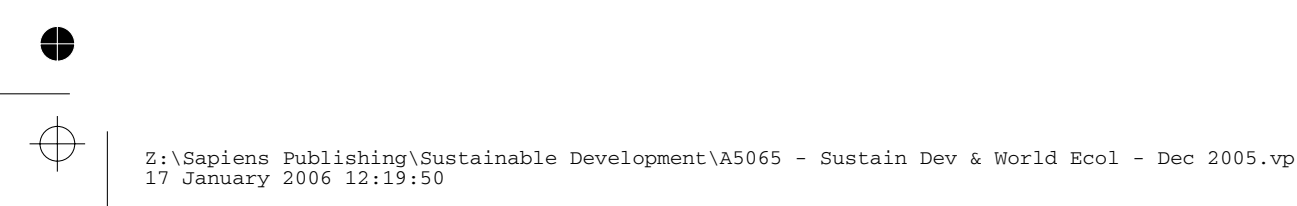


gradually (Figure 3) for wheat from $11.59 \times 10^{6}$ tonnes in 1995 to $0.88 \times 10^{6}$ tonnes in 2000 , and for maize from $5.18 \times 10^{6}$ tonnes in 1995 to zero in 2000 , because domestic supply has increased. However, in contrast to declining imports, the volume of export products has increased from 1980 to 2000 due to increasing production because of improved agricultural technologies. Growing export products include rice, cotton, pork and fishery products (Figure 4, 5), in which rice export rose from $0.05 \times 10^{6}$ tonnes in 1995 to $3.75 \times 10^{6}$ tonnes in 1998 (Figure 4). Pork exports declined from $3.24 \times 10^{6}$ tonnes in 1982 to $1.96 \times 10^{6}$ tonnes in 1999 because of increased domestic demand.

With the limited potential for additional water supply, the pursuit of water sources for the improvement of water use efficiency has shifted to high-value crops. Vegetables and fruits are typically encouraged in China as economic agricultural products and as a way of raising rural incomes. The exports of vegetables and fruit increased from 1980-2000 (Figure 6). This shift has produced high economic returns and made possible more selections of imports for the alleviation of the intensification of water stress.

\section{ANALYSIS OF THE ROLE OF \\ VIRTUAL WATER}

\section{Virtual water implications}

Allan defined 'virtual water' as the water embodied in food crops that are traded internationally (Allan 1996a,b, 1998). Allan (1997) termed such food imports as 'virtual imports' due to the fact that they are equivalent to a transfer of water to the importing countries. The concept is used to describe a water-scarce nation's opportunities for achieving food security by purchasing a portion of its food requirements in the international market. It compares the amount of water embodied in a crop that can be purchased internationally with the amount of water which would be required to produce that crop domestically (Wichelns 2001). Virtual water is a term that links water, food and trade (Allan 2003). As the metaphor of virtual water gained currency in the mid-1990s, economists at the World Bank started to use another term the 'water, food and trade nexus' (McCalla 1997). This combines agronomic, economic and political outlooks, with emphasis on water as the key factor of production.

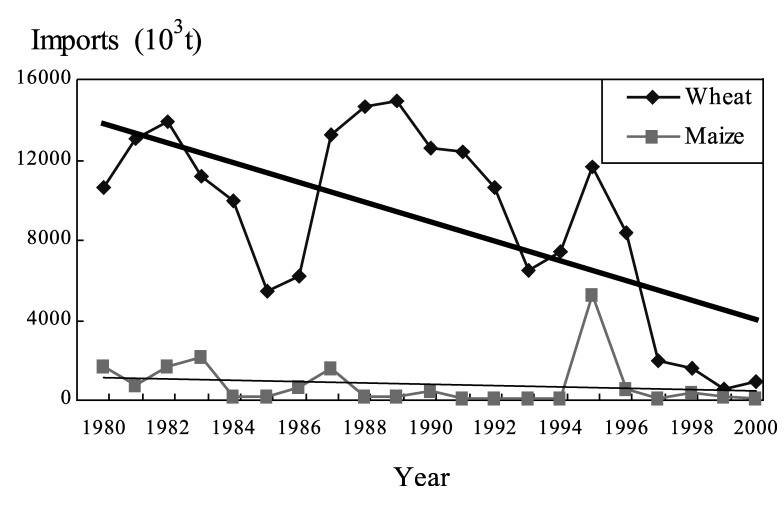

Figure 3 Imports of wheat and maize, 1980-2000

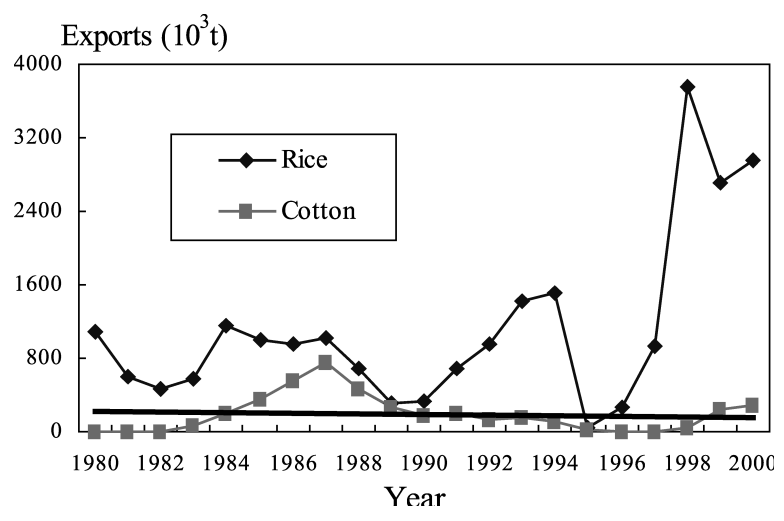

Figure 4 Exports of rice and cotton, 1980-2000

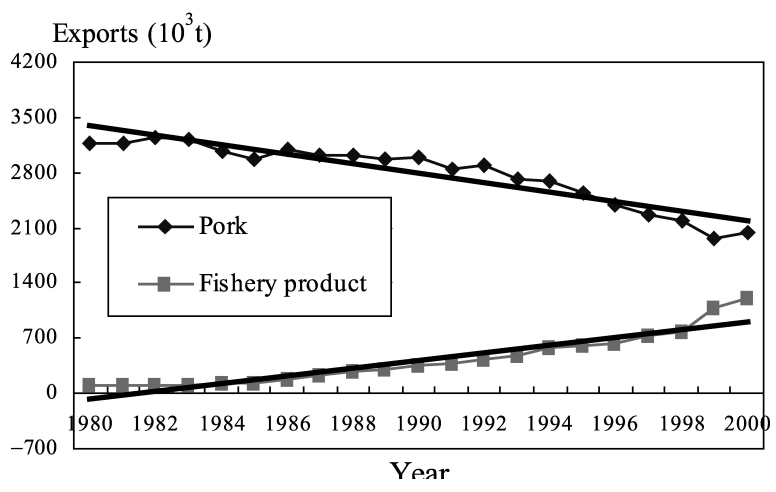

Figure 5 Exports of pork and fishery products, 1980-2000

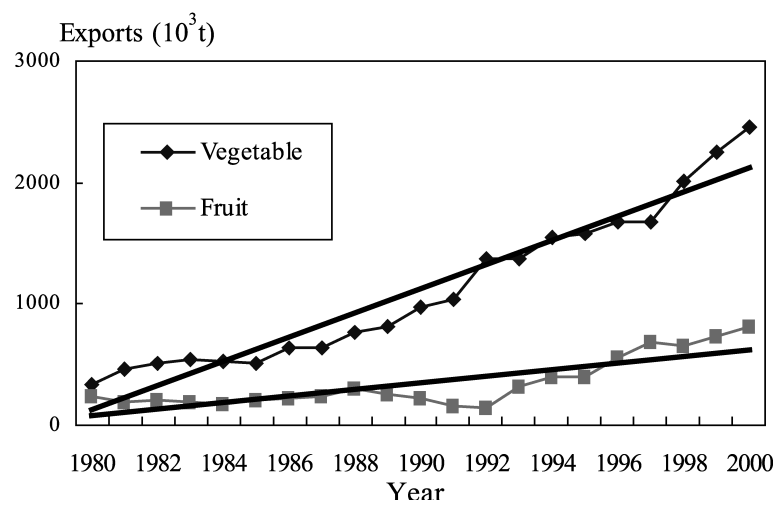

Figure 6 Exports of vegetable and fruit, 1980-2000 
The agronomic component involves the opportunity cost of water, which may include production of alternative crops or use in municipal, industrial or recreational activities (Bouwer 2000; Wichelns 2001). The opportunity cost of water use, which is a key component of the 'virtual water' perspective must be considered when seeking an efficient allocation of scarce water resources. The same concept applies to the water embodied in other productive activities, such as manufacturing and power generation. Some manufactured goods require a greater amount of water in the production process than other goods. Nations in which water is particularly scarce may gain by importing water-intensive manufactured goods, while exporting goods that require less water in production. Similarly, nations with limited freshwater resources may gain by generating electricity in coastal areas, using ocean water for cooling, or by importing electricity from countries with abundant hydroelectric resources (Bouwer 2000, 2003).

\section{Policy relevance of virtual water}

Food trade plays an important role in redistributing the water resources of the world. The role of food imports in compensating water scarcity is elaborated with a quantitative accounting of the volume of virtual water embedded in their food imports. It is suggested that water be considered an economic good (Hoekstra et al. 2003a,b), and virtual water trade be seen as an instrument to achieve food security and efficient water use (Hofwegen et al. 2003). However, when water policy issues are discussed, further implications of virtual water can be considered. Food imports are used when policy makers care about food security, while the feasibility of food imports is judged by opportunity cost. Wichelns (2003), however, thought that the optimal trading strategy could be determined by examining the comparative advantage, not the opportunity cost. This comparative advantage includes consideration of the water resource endowment and the production technologies in two or more countries that can engage in trade.

On the other side, virtual water has geopolitical implications. Trade induces dependence between countries, and it is influenced by and has implications on tariffs. Indeed, the issue of virtual water is related to globalization, which raises concerns among many politicians and the general public. Increasing global trade implies increased interdependence of nations (Hofwegen et al. 2003). Geopolitical conditions in food trade are not ignored because food security, like water security, is a highly contentious issue that needs carefully examining in terms of the degree and method of food self-sufficiency. Domestic political power has decided traded objectives, volumes and formations (Kang 2000). Bouwer (2000) suggested that an OFEC (Organization of Food Exporting Countries) be established with international controls, and in which the importing countries are ensured that global distribution of food will not be used as a political weapon. This study emphasizes the potential role of virtual water trade on the solution to water resource scarcity and food security.

\section{Virtual water equivalents in traded food}

Food production is constrained by water scarcity; thus, importing food compensates for scarce water resources. Table 2 presents estimates of the volumes of virtual water embedded in traded wheat and maize in different years. Virtual land is also evaluated using imports divided by yields per hectare in the same year from the FAO statistics, where virtual water is the amount of imports multiplied by the global average of virtual water in every crop (Hoekstra and Hung 2003). On average, $8.9 \times 10^{6}$ tonnes of wheat and $0.9 \times 10^{6}$ tonnes of maize were imported annually between 1980 and 2000 (Table $6)$. An average of $10.20 \times 10^{9} \mathrm{~m}^{3}$ water and $27.7 \times 10^{6}$ ha of land would be required to produce this imported wheat, while an average of $0.32 \times 10^{9} \mathrm{~m}^{3}$ water and $1.6 \times 10^{6}$ ha land would be required to produce the imported maize. The sum of $10.52 \times 10^{9} \mathrm{~m}^{3}$ of virtual water is equivalent to $23 \%$ of the annual average transfer of water volume for the South-North Water Transfer (SNWT) project. From 1995 to 1999, net virtual water import volume of crops in China was calculated at $101.9 \times 10^{9} \mathrm{~m}^{3}$, and China became the fifth in the top-30 table of net virtual water countries (Hoekstra and Hung 2003). The sum of $29.3 \times 10^{6} \mathrm{~m}^{3}$ of virtual land is equivalent to $19 \%$ of crop arable land in 2000 
Table 6 Virtual water equivalent embedded in traded food

\begin{tabular}{lcccc}
\hline & $\begin{array}{c}\text { Domestic } \\
\text { production/ } \\
10^{6} t\end{array}$ & $\begin{array}{c}\text { Imports/ } \\
10^{6} t\end{array}$ & $\begin{array}{c}\text { Virtual } \\
\text { water/ } \\
10^{9} \mathrm{~m}^{3}\end{array}$ & $\begin{array}{c}\text { Virtual } \\
\text { land/ } \\
10^{6} \mathrm{hm}\end{array}$ \\
Year & & & & \\
Wheat & 68.5 & 13.8 & 15.87 & 56.3 \\
1982 & 81.4 & 11.1 & 12.78 & 39.7 \\
1983 & 90.8 & 14.9 & 17.11 & 48.9 \\
1989 & 102.2 & 11.6 & 13.33 & 32.7 \\
1995 & 113.9 & 0.5 & 0.52 & 1.1 \\
1999 & 99.6 & 0.9 & 1.01 & 2.4 \\
2000 & 96.8 & 8.9 & 10.20 & 27.7 \\
Mean & & & & \\
Maize & 60.7 & 1.6 & 0.71 & 4.8 \\
1982 & 68.4 & 2.1 & 0.95 & 5.8 \\
1983 & 78.9 & 0.1 & 0.32 & 0.2 \\
1989 & 112.0 & 5.2 & 2.33 & 10.5 \\
1995 & 128.1 & 0.1 & 0.03 & 0.1 \\
1999 & 106.0 & 0.0 & - & - \\
2000 & 93.5 & 0.9 & 0.32 & 1.6 \\
Mean & & & \\
\hline
\end{tabular}

Sources: Statistics yearbook 2000, 2001

\section{Water compensation through virtual water}

Water resource scarcity constrains food production, and food supply cannot completely depend on the enlargement of food production. The basic food supply comes from food production and imports. Food import is appropriate when food price is lower than domestic production cost in the international market (Allan 1999). For virtual water embedded in the cereal imports, an aggregate ratio of $1 \mathrm{~kg}$ grain to $1 \mathrm{~m}^{3}$ of water is used. As such, the figures for cereal imports (Table 7) can be transformed into the same numeric volumes of virtual water in $\mathrm{m}^{3}$ / per capita. Research shows that virtual water volume embodied in cereal is higher than the global average (Oki et al. 2003). This means that imports of virtual water in China should be greater than estimates in this study.

The factors that influence opportunity cost of production caused by the growth of irrigation water volume to enlarge the food supply have two aspects One is the food supply capacity including food demand, food alternatives, food productive capacity and native import capacity. The native import capacity includes international food prices, native foreign trade conditions and international aid. The
Table 7 China's net food imports and virtual water equivalents for 2000-2030

\begin{tabular}{ccccc}
\hline Cereal & $\begin{array}{c}\text { Foodstuff } \\
\text { imports } \\
\left(10^{6} t\right)\end{array}$ & $\begin{array}{c}\text { Virtual water } \\
\text { embedded } \\
\text { in cereal } \\
\left(10^{6} t\right)\end{array}$ & $\begin{array}{c}\text { Virtual water } \\
\text { embedded in } \\
\text { foodstuff } \\
\left(10^{9} \mathrm{~m}^{3}\right)\end{array}$ \\
\hline 2000 & 32 & 34 & 32.0 & 36.0 \\
2010 & 80 & 84 & 80.0 & 88.0 \\
2020 & 86 & 91 & 86.0 & 96.0 \\
2030 & $-26^{1}$ & -28 & $/ /^{2}$ & $/$ \\
\hline
\end{tabular}

${ }^{1}$ Exports exceed imports, so the numbers are negative ${ }^{2}$ There is no virtual water import because of negative net food import

other aspect is concerned with water resources, embodied in water use efficiency in agriculture, agriculture management, water resource volume, water pollution, wastewater treatment and reuse. Those limiting factors are complex and, when combined, the opportunity cost in different nations and regions are obviously different. The amount of agricultural produce derived from a certain amount of water is subject to a large number of variables. These include the geographic location of the region where crops are grown, the irrigation system used, the management of the irrigation system, soil types and climatic conditions (Turton et al. 2002).

Moving virtual water will be much cheaper than moving water itself (Bouwer 2003). Global movement of food from water-rich to water-poor countries should be just as feasible as moving petroleum products from oil-rich to oil-poor countries. Virtual water opportunities for saving local water resources include imports of electric power from areas with more abundant water for cooling of thermal power plants, or with dams for hydroelectric power production (Bouwer 2000). Currently, most researchers in China think food demand and supply in China are on firm ground (Wang 1999; Wang and Lang 2002; Cheng 2003; Kang 1998; Chen et al. 2001). Some agreed that the food import dependence ratio might be augmented to 20\% (Wang et al. 2002), while others argued that food supply should be self-dependent to ensure food security and food trade between regions within China (Cheng 2003). Virtual water is useful to alleviate water scarcity pressure, but many governments are worried that over-dependence on other nations will result in a food crisis and social instability. 


\section{CONCLUSIONS}

Importing virtual water embedded in traded food in China can be seen to alleviate water stress, and even achieve food security. Virtual water trade may compensate for water demands of not only the past but also the future. Meanwhile, the trade can store water in its virtual water form, especially by food storage, to play a potential role in solving food problems. However, policy considerations of domestic water and food security are needed to promote better understanding of the

\section{REFERENCES}

Allan JA. The political economy of water: reasons for optimism but long-term caution. In Allan JA (ed.), Water, Peace and the Middle East: Negotiating Resources in the Jordan Basin. London: Tauris Academic Studies; 1996a

Allan JA. Policy responses to the closure of water resources: regional and global issues. In Howsam $P$ and Carter RC (eds), Water Policy: Allocation and Management in Practice. London: Chapman and Hall; 1996b

Allan JA. Virtual water: a strategic resource. Global solutions to region deficits. Ground Water 1998;36(4):545-464

Allan JA. A convenient solution. The UNESCO Courier 1999;52(2):29-31

Allan JA, Merrett S and Lant C. Virtual water- the water, food, and trade nexus useful concept or misleading metaphor? Occasional Paper, Water Issues Study Group School of Oriental and African Studies (SOAS). www2.soas.ac.uk/geography/ waterissues/occacional paper/home.html; 2003

Bennett AJ. Environmental consequences of increasing production: some current perspectives. Agricultural Ecosystem Environment 2000;82:89-95

Bouwer H. Integrated water management: emerging issues and challenges. Agricultural Water Management 2000;45:217-28

Bouwer H. Integrated water management for the 21st century: Problems and Solutions. Food, Agriculture Eै Environment 2003;1 (1):118-27

Chen Y et al. Water demand and irrigation of main crops in China. Beijing: Hydropower Publishing House; 1995

Cheng GD. Virtual water ${ }^{-}$a new idea of water resources security. Journal of Eco-economics 2003;1 (2):75-9

Cohen JE. How many people can the earth support? London \& New York: W. W. Norton \& Co.; 1996

FAO. http://www.fao.org/ag/; 2001 measures that need to be taken to ensure their future supply.

\section{ACKNOWLEDGEMENTS}

The Initiation Science Project from the Chinese Academy of Sciences (KZCX3-SW-423 KZCW3SW-438), China's Natural Foundation (70325002 70403014) and EU project (ICA4-2002-10004) supported this research financially. The authors thank Professor Wichelns for his helpful suggestions.

FAO. http://www.fao.org/waicent/portal/statistics_en.asp; 2004

Hoekstra AY and Hung PQ. Virtual water trade: A quantification of virtual water flows between nations on relation to international crop trade. In Hoekstra AY (ed.), Virtual Water Trade: Proceedings of the International Expert Meeting on Virtual Water Trade. Research Report Series No. 12. IHE Delft: The Netherlands 2003:25-47

Hoekstra AY. Virtual water: An introduction. In Hoekstra AY (ed.), Virtual Water Trade: Proceedings of the International Expert Meeting on Virtual Water Trade. Research Report Series No. 12. IHE Delft: The Netherlands 2003a:13-23

Hoekstra AY. The role of virtual water transfer in water management. Paper presented at the International Workshop on European Water Scenarios: from the Mediterrenean Sea to Central Asia. Brussels, Belgium; 30 June-1 July; 2003b

Hong Y. Water, environment and food security: a case study of the Haih River basin in China. Ecology and the Environment 2003;60:27-36

Hong $\mathrm{Y}$ and Zehnder AJB. Water Scarcity and Food Import: A Case Study for Southern Mediterranean Countries. World Development 2002;30(8):1413-30

Hong Y. China's 21st century water security. Environmental Protection 1999;10:29-31

Huddleston B. FAO's overall approach and methodology for formulating national food security programs in developing countries. IDS Bulletin 1990;21 (3):72-80

Kang XG. Chinese Food International - Trade and Food Security. Tianjin: Tianjin Renmin Press; 1998

Kang XG. analysis of China's food import global effects during 2000-2050. http://www.csdn618. com.cn/century/wencui/oldwencui/zhoukan/ 0828adaj01.htm; 2000 
Kennes W. The European community and food security. IDS Bulletin 1990;21 (3):67-71

Liu CM. Water Resources Development in the Firs Half of 21st Century in China. Second World Water Forum, China Water Vision. 2000;1-6

Maxwell S. Food security in developing countries: issues and options for the 1990s. IDS Bulletin 1990;21 (3):2-13

McCalla A. The water, food, and trade nexus. Paper delivered at MENA-MED Conference convened by the World Bank in Marrakesh, May 1997

Oki T, Sato M, Kawamura A, Miyake M, Kanae S and Musiake K. Virtual water trade to Japan and in the world. In Hoekstra AY (ed.), Virtual Water Trade: Proceedings of the International Expert Meeting on Virtual Water Trade. Research Report Series No. 12. IHE Delft: The Netherlands; 2003

Qadir M, Boers ThM, Schubert S, Ghafoor A and Murtaza G. Agricultural water management in water-starved countries: challenges and opportunities. Agricultural Water Management 2003;62: 165-85

Qian ZYand Zhang GD. Comprehensive and Special Statements of China's Sustainable Development Strategy of Water Resources. Beijing: China water control \& hydropower press; 2001

Qu GP et al. (deeds). China's population and Environment. Beijing: China Environmental Science Press; 1992

Rosgrant M and Perez M. Water resources development in Africa: a review and synthesis of issues, potentials, and strategies for the future. Discussion Paper No. 28. International Food Policy Research Institute, Washington DC; 1997

Seckle D and Amarasinghe U. Major problems in the global water-food nexus. Occasional Paper, Water Issues Study Group School of Oriental and African Studies (SOAS). www2.soas.ac.uk/geography/ waterissues/occacional paper/home.html; 2001
Shaw DJ and Clay EJ. Global hunger and food security after the world Food Summit. Cannadian Journal of Development Studies 1998;19:55-76

Turton AR, Moodley S, Goldblatt M and Meissner R. Global water resources: vulnerability from climate change and population growth. Science 2002;289: 284-8

Turton AR. Water scarcity and social adaptive capacity: towards an understanding of the social dynamics of water demand management in developing countries. MEWREW Occasional Paper Water Issues Study Group School of Oriental and African Studies (SOAS). www2.soas.ac.uk/geography/ waterissues/occacional paper/home.html; 1999

van Hofwegen P and Zimmer D. Virtual water trade conscious choice. Discussion paper at e-mail conference on virtual water trade and geopolitics, August 2003

Wang YZ. International security of globalization times. Shanghai: Shanghai Renmin Press; 1999

Wang LM and Lang YH. Study progress and problems of China's resource security. Progress in Geography 2002;21 (4):333-40

Wichelns D. The role of 'virtual water' in efforts to achieve food security and other national goals, with an example from Egypt. Agricultural Water Management 2001;49:131-51

Wichelns D. The policy relevance of virtual water can be enhanced by considering comparative advantages. Agricultural Water Management 2004;66(1): 49-63

World Bank. Poverty and Hunger: Issues and Options for Food Security in Developing Countries. A World Bank Policy Study, Washington, DC; 1986

Yan RZ and Chen SL. Economic Globalization and China's Food Problems. Beijing: Renmin University of China Press; 2001 